\title{
INTERPRETASI STRUKTUR GEOLOGI PADA AREA GEOPARK CILETUH DENGAN ANALISIS DERIVATIF DATA GAYABERAT GGMPLUS
}

\section{INTERPRETATION OF GEOLOGICAL STRUCTURE IN}

\section{GEOPARK CILETUH AREA WITH DERIVATIVE}

\section{ANALYSIS OF GGMPLUS GRA VITY DATA}

\author{
Adib Ihsan Panggabean ${ }^{1^{*}}$, Iskandarsyah ${ }^{1}$, William Jhanesta ${ }^{1}$ \\ 1Program Studi Geofisika, Departemen Geosains, U niversitas Indonesia \\ 2enerGIS Indonesia, Beji, Depok, Indonesia
}

Received: 2021, August 29 $9^{\text {th }}$

Accepted: 2021, October $31^{\text {th }}$

\section{Keywords: \\ Derivative; \\ Geopark Ciletuh; \\ Gravity;}

Structure.

\section{Corespondent Email:}

adib.ihsan@ui.ac.id

\section{H ow to cite this article:}

Panggabean, A.I.,

Iskandarsyah, \& J hanesta, W. (2021). Interpretasi Struktur

Geologi pada A rea Geopark

Ciletuh dengan A nalisis

Derivatif Data Gayaberat
Abstrak. Geopark Ciletuh terletak di Kecamatan Ciemas sebelah barat Kabupaten Sukabumi, Jawa Barat, Indonesia. Pada Geopark Ciletuh terdapat adanya batuan Pra-Tersier yang tersingkap di permukaan dan juga terdapat berbagai macam struktur yang terbentuk akibat terjadinya pergerakan tektonik di sebelah barat daya Geopark Ciletuh. Penelitian ini dilakukan bertujuan mendelineasi struktur pada Geopark Ciletuh yang timbul oleh adanya perbedaan densitas dengan metode gaya berat. Pada penelitian ini digunakan analisis derivatif first horizontal derivative (FHD) untuk mengetahui keberadaan struktur dan second vertical derivative (SVD) untuk menentukan jenis patahan. Pada penelitian ini juga dilakukan dip estimation dengan metode multi-level second vertical derivative (M L-SVD). Setelah didapatkan data FHD, SVD, dan ML-SVD selanjutnya diintegrasikan dengan data geological section dari peta geologi Lembar Jampang Balekembang untuk dibuat penampang geologi. Interpretasi dugaan patahan memiliki arah orientasi NW-SE dan NESW. Hasil penelitian menujukkan adanya indikasi dugaan patahan naik dan patahan turun. Pada analisis terpadu, didapatkan adanya kesesuaian maupun ketidakkesesuaian antara data peta geologi dengan data geofisika.

Abstract. Ciletuh Geopark is located in Ciemas District, west of Sukabumi Regency, W est Java, Indonesia. In Ciletuh Geopark, there are Pre-Tertiary rocks exposed on the surface. There are also various kinds of structures formed due to tectonic movements in the southwest of Ciletuh Geopark. This research was conducted to delineate the existing structures in the Ciletuh Geopark, using the gravity method to map the gravitational anomaly caused by differences in 
GGM plus. Jurnal Geofisika

Eksplorasi, 07(03), 226-237.

(C) 2021 J GE (Jurnal Geofisika Eksplorasi). This article is an openaccess article distributed under the terms and conditions of the Creative Commons Attribution (CC BY NC) density. In this study, the first horizontal derivative (FHD) analysis was used to determine the existence of the structure and the second vertical derivative (SVD) to determine the type of fault. Dip estimation was also carried out using the multi-level second vertical derivative (ML-SVD) method in this study. After obtaining FHD, SVD, and M L-SVD data, it was then integrated with geological section data from the geological map of the Jampang Balekembang Sheet for making geological cross-sections. Interpretation of the alleged fault has an orientation of NW-SE and NE-SW. The results of the study show that there are indications of suspected ascending and descending faults. In the integrated analysis, it is found that there is a match or discrepancy between the geological map data and the geophysical data.

\section{PENDAHULUAN}

Sukamto (1975) melakukan pemetaan geologi pada daerah Jampang dan Balekembang termasuk di dalamnya kawasan Geopark Ciletuh. Berdasarkan peta geologi yang dibuat Sukamto, terbukti bahwa terdapat adanya batuan Pra-Tersier yang tersingkap di permukaan sebelah barat kawasan Geopark Ciletuh dan terdapat adanya sebuah landskap dataran tinggi yang memanjang dan menghadap ke arah laut. Pada peta geologi oleh Sukamto, terdapat adanya beberapa patahan dengan berbagai macam karakteristik yang terbentuk akibat terjadinya pergerakan tektonik di sebelah barat daya Geopark Ciletuh.

Pada wilayah penelitian sebelumnya belum pernah dilakukan adanya survei metode geofisika. Salah satu metode geofisika yang dapat digunakan untuk mendelineasi struktur yaitu dengan metode gayaberat. M etode gayaberat merupakan survei awal yang memiliki kelebihan memberi informasi terkait kontras densitas batuan dan struktur geologi dengan cukup detail (Hidayat \& Basid, 2011). Data anomali residual gayaberat selanjutnya digunakan untuk memetakan dan mendelineasi keberadaan struktur dengan dilakukan metode first horizontal derivative (FHD) dan second vertical derivative (SVD). Nilai FHD dapat digunakan untuk menunjukkan keberadaan patahan. Sedangkan SVD digunakan untuk menimbulkan efek dangkal agar dapat terdeteksi jenis struktur patahan (W achidah \& M inarto, 2018).

\section{TINJAUAN PUSTAKA}

Kawasan Geopark Ciletuh berdasarkan data administratif berada di Kecamatan Ciemas, Kabupaten Sukabumi, Provinsi Jawa Barat. Pada Gambar 1 kawasan Geopark Ciletuh terletak pada Peta Geologi Lembar Jampang dan Balekambang. Secara geomorfologi, Geopark Ciletuh terletak pada kompleks T eluk Ciletuh yang berada di zona Pegunungan Selatan Jawa morfologi pegunungan yang memiliki ketinggian bervariasi (Rosana dkk., 2006) dengan keunikan terdapatnya singkapan kelompok batuan berumur Pra-Tersier hingga Pra-Eosen tengah yang menjadi salah satu daerah tertua di Pulau Jawa (Sarmili \& Setiady, 2015). Keunikan lain pada lokasi ini yaitu terdapatnya lembah yang menyerupai amfiteater dengan bentuk tapal kuda yang di dalamnya terdapat seluruh singkapan batuan (Andriany dkk., 2016).

Geopark Ciletuh berdasarkan karakteristik di lapangan dapat dibedakan menurut bentukan asal menjadi tiga, yaitu morfologi bentukan asal fluvial, bentukan asal struktur, dan bentukan asal laut (Rosana dkk., 2006). Morfologi bentukan asal fluvial memiliki bentang alam berupa dataran aluvial, morfologi bentukan asal struktur dicirikan dengan bentang alam perbukitan berpuncak meruncing dan membundar, dan morfologi 
bentukan asal pasir dicirikan dengan bentang alam lahan pasir yang memiliki luas wilayah sekitar 10\% dari kawasan Geopark Ciletuh (Rosana dkk., 2006).
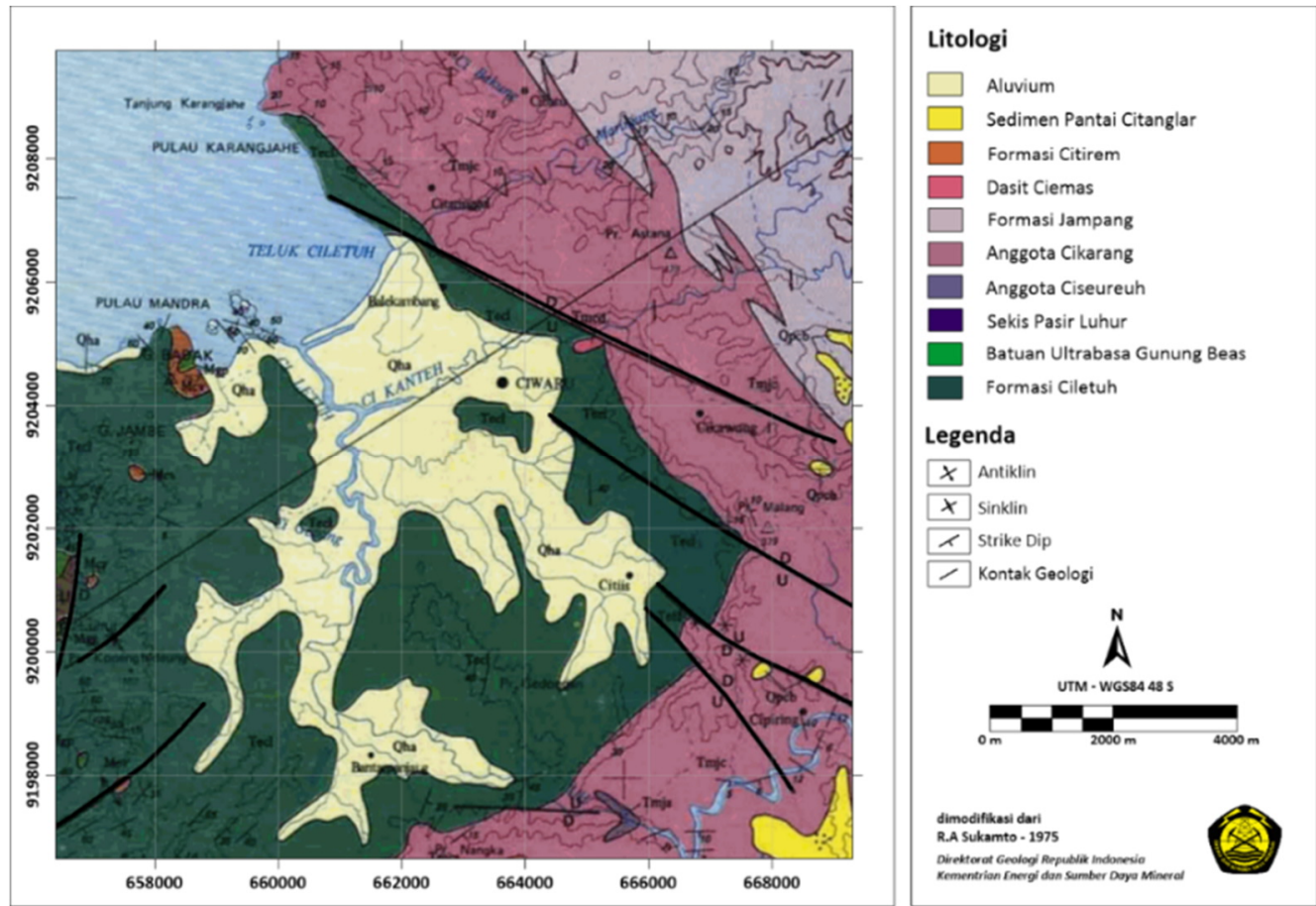

Gambar 1. Peta Geologi Kawasan Ciletuh modifikasi dari Sukamto (1975).

\section{METODE PENELITIAN}

\subsection{First H orizontal Derivative}

Turunan pertama horizontal atau FHD biasa disebut juga sebagai gradien horizontal. FHD adalah nilai laju perubahan gayaberat dalam arah horizontal dengan satuan $\mathrm{mgal} / \mathrm{km}$. A nomali gayaberat mengalami perubahan gradien horizontal terbesar terjadi ketika benda tabular cenderung berada di ujung-ujung bodi batuan (Blakely, 1995). Maka dari itu, dapat disimpulkan bahwa perubahan anomali yang cenderung signifikan menandakan adanya batas struktur geologi dengan nilai FHD dengan titik puncak maksimum dari kurva (Rosid \& Siregar, 2017). Nilai FHD diperoleh dengan persamaan (Blakely, 1995):

$$
F H D=\sqrt{\left(\frac{\partial g}{\partial x}\right)^{2}+\left(\frac{\partial g}{\partial y}\right)^{2}}
$$

Dimana, $\frac{\partial g}{\partial x}$ dan $\frac{\partial g}{\partial y}$ adalah turunan pertama dari anomali gayaberat pada arah $\mathrm{x}$ dan $\mathrm{y}$.

\subsection{Second Vertical Derivative}

Terdapat sebuah masalah yang inheren ketika melakukan interpretasi pada peta Anomali Bouguer tidak cukup mampu memisahkan efek struktur pada kedalaman dangkal dengan kedalaman yang dalam. Dihapusnya efek regional pada data anomali Bouguer memberikan hasil residual tidak spesifik dan tidak pasti. Oleh karena itu, dibutuhkan turunan vertikal kedua atau second vertical derivative untuk memberikan efek yang lebih spesifik (Reynolds, 1997).

Second vertical derivative (SVD) digunakan sebagai high pass filter yaitu mengabaikan anomali di posisi lebih dalam dengan meningkatkan efek yang berada dekat dengan permukaan. Maka, hasil diperoleh akan berasosiasi terhadap struktur dangkal (Fitriani 
dkk., 2020). SVD bisa didapatkan melalui penurunan horizontal dikarenakan medan gayaberat mencukupi persamaan Laplace, ditulis dengan persamaan sebagai berikut:

$$
\begin{aligned}
& \nabla^{2} g=\frac{\partial^{2} g}{\partial x^{2}}+\frac{\partial^{2} g}{\partial y^{2}}+\frac{\partial^{2} g}{\partial z^{2}}=0 \\
& \frac{\partial^{2} g}{\partial z^{2}}=-\left(\frac{\partial^{2} g}{\partial x^{2}}+\frac{\partial^{2} g}{\partial y^{2}}\right)
\end{aligned}
$$

Dimana, $\frac{\partial^{2} g}{\partial x^{2}}, \frac{\partial^{2} g}{\partial y^{2}}$, dan $\frac{\partial^{2} g}{\partial z^{2}}$ adalah turunan kedua dari anomali gayaberat pada $\operatorname{arah} x, y$, dan $z$.

Hasil perhitungan SVD dapat berfungsi mengidentifikasi terkait dengan jenis patahan (Sriyanto \& Ifantyana, 2016 dalam Fitriani dkk., 2020). Dalam persamaan (4) dan (5) seperti berikut (Kearey dkk., 2002):

$$
\begin{aligned}
& \left(\frac{\partial^{2} g}{\partial z^{2}}\right)_{\max }>\left(\frac{\partial^{2} g}{\partial z^{2}}\right)_{\text {min }} \text { patahan normal (4) } \\
& \left(\frac{\partial^{2} g}{\partial z^{2}}\right)_{\max }<\left(\frac{\partial^{2} g}{\partial z^{2}}\right)_{\text {min }} \text { patahan naik }
\end{aligned}
$$

\subsection{Multi-Level Second Vertical Derivative}

ML-SVD merupakan suatu teknik atau metode SVD yang diperoleh dari data anomali gayaberat yang telah dilakukan proses upward continuation sebanyak-n (Rosid \& Jaidi, 2020). Dalam penelitian ini, yang dilakukan proses upward continuation adalah data residual gayaberat yang kemudian dilakukan proses SVD. Seperti yang ditunjukkan oleh Gambar $\mathbf{2}$ nantinya akan didapatkan respon SVD nilai "0" yang berasal dari anomali gayaberat yang tidak dilakukan UC dan juga didapatkan respon SVD nilai " 0 " yang berasal dari anomali gayaberat yang telah dilakukan UC dimulai dari 0-2000 meter dengan interval 200 meter. Nilai dip diperoleh dengan menghitung arctan dari nilai gradien hasil persamaan regresi linier antara fault location yang mengindikasikan SVD nilai " 0 " dan UC level (Jhanesta \& Supriyanto, 2021).

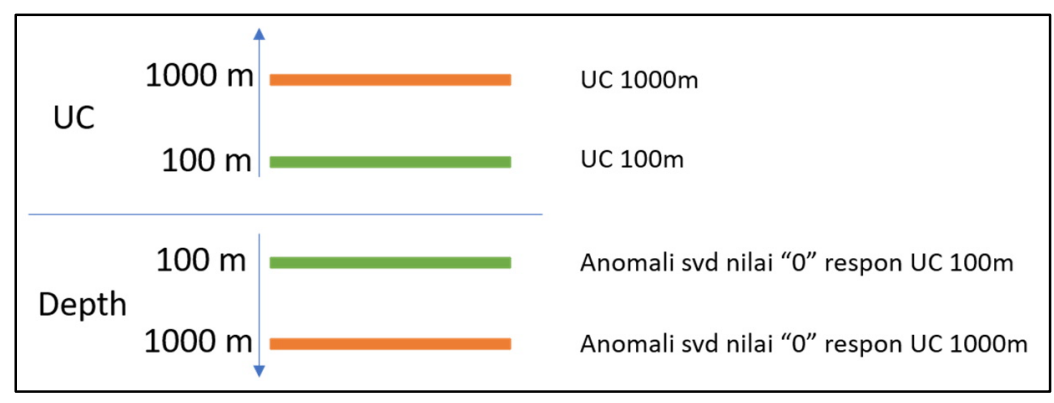

Gambar 2. Konsep U pward Continuation (Rosid \& Jaidi, 2020).

\section{HASIL DAN PEMBAHASAN}

Berdasarkan data densitas parasnis, lokasi penelitian memiliki densitas rata-rata batuan bawah permukaan sebesar $2,59 \mathrm{~g} / \mathrm{cm}^{3}$. Perhitungan nilai densitas memiliki kesesuaian dengan litologi batuan lokasi penelitian yang didominasi oleh breksi polimik dengan komponen batuan melange dan batuan ofiolit serta batuan andesit dan juga terdapat adanya batuan sedimen (Andriany dkk., 2016).

\subsection{Complete Bouguer Anomaly}

Dihasilkan peta A nomali Bouguer Lengkap (CBA) seperti pada Gambar 3 dengan rentang nilai anomali gayaberat antara 180-228 mGal. Terlihat nilai anomali gayaberat yang tertinggi berada pada bagian tenggara dikarenakan daerah tersebut relatif lebih jauh dari laut. Sedangkan daerah dengan anomali rendah berada pada bagian barat laut dikarenakan 
daerah ini didominasi oleh adanya aluvium dan berada dekat dengan garis pantai dengan diduga adanya intrusi air laut.

\subsection{Anomali Regional dan Residual}

Pada Gambar $\mathbf{4}$ anomali regional memiliki rentang nilai yang berkisar $180-228 \mathrm{mGal}$. A rah orientasi struktur yang ditunjukkan oleh peta anomali regional menunjukkan adanya kesesuaian dengan arah orientasi W-E dan NE-SW yang mengikuti pola Meratus (Hilmi \& Haryanto, 2008). Pada Gambar 5, anomali residual memiliki tiga pola anomali yaitu tinggi (0,3 hingga $1,7 \mathrm{mGal})$, sedang $(-0,3$ hingga 0,3 $\mathrm{mGal})$, dan rendah (-1,3 hingga $-0,3 \mathrm{mGal}$ ).

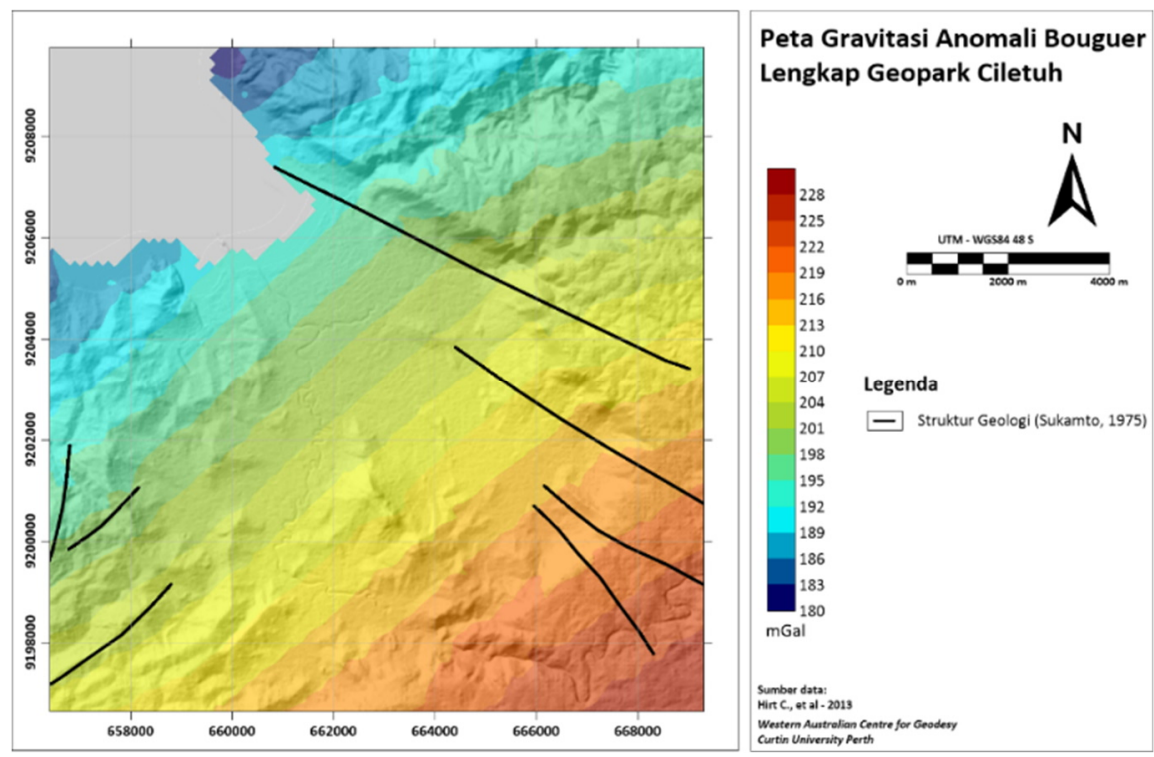

Gambar 3. Peta Gayaberat A nomali Bouguer Lengkap.
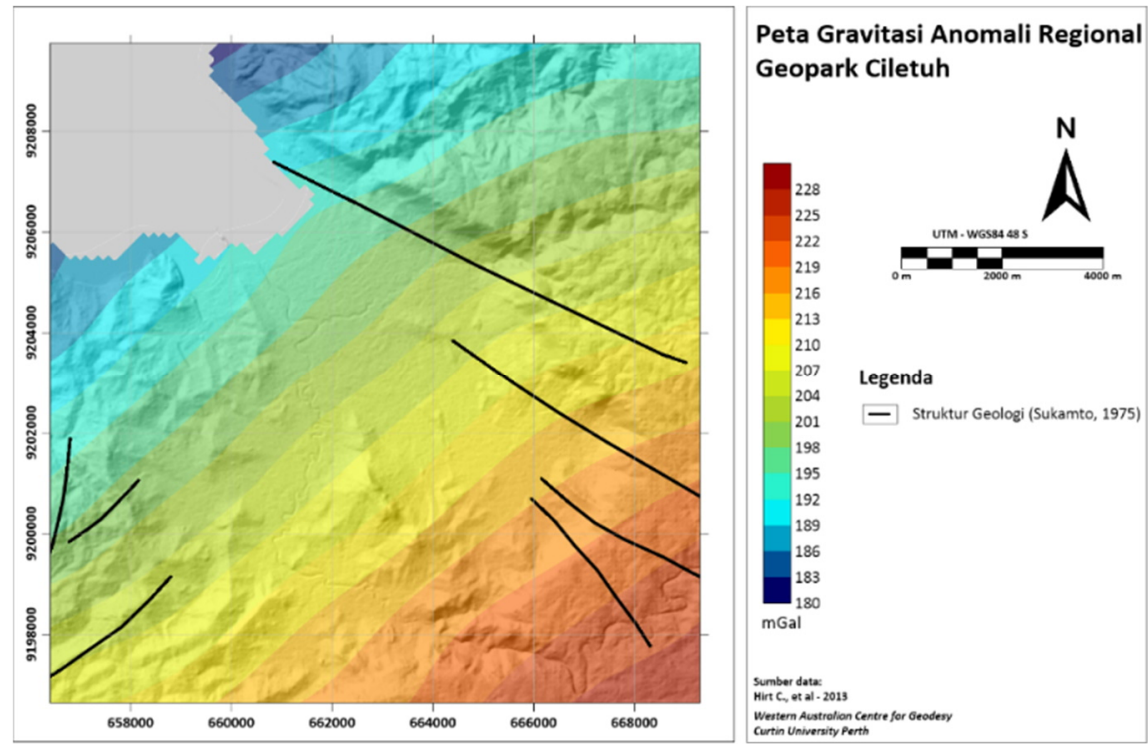

Gambar 4. Peta Gayaberat Anomali Bouguer Regional.

\subsection{Analisis FHD dan SVD}

Pada Gambar 6 peta gayaberat anomali FHD dan SVD, dilakukan penarikan interpretasi dugaan adanya struktur patahan sebanyak sepuluh garis yang diberi nama F1F10. Penarikan interpretasi ini dilakukan 
sesuai dengan struktur patahan yang terdapat pada permukaan Peta Geologi Lembar Jampang Balekembang yang dibuat oleh Sukamto (1975) dan dikorelasikan dengan peta gayaberat anomali FHD dan SVD. Pada peta terdapat juga slicing line yang diberi nama line $A-A^{\prime}$, line $B-B^{\prime}$, line $C-C^{\prime}$, dan line $D-D^{\prime}$ dengan tujuan untuk mengetahui kebenaran adanya struktur patahan dan jenis patahan. Berdasarkan analisis diagram Rosset pada Gambar 7 yang didapatkan dari data geologi dan data geofisika, didapatkan arah orientasi sebaran orientasi strike struktur yang berada di area penelitian. Kedua diagram menunjukkan orientasi struktur dominan berarah yang sama yaitu NW-SE.

Data anomali FHD maksimum pada
Gambar 8 bertujuan untuk menentukan adanya batas objek geologi berupa patahan dan lipatan pada umumnya, yang ditandai dari keterdapatan adanya nilai anomali lebih tinggi dari sekitar pada area. Di sisi lain, anomali SVD nilai nol dapat dimanfaatkan untuk mengonfirmasi keberadaan objek berupa struktur patahan atau lipatan serta menentukan arah pergerakan dari patahan tersebut (Fitriastuti dkk., 2019). Pada Gambar 8 line A-A' memotong dugaan adanya struktur patahan $F 1$ dan $F 2$, line B-B' memotong dugaan adanya struktur patahan F3 dan F4, line $C-C^{\prime}$ memotong dugaan adanya struktur patahan F5, F6, dan F7, dan line $D-D^{\prime}$ memotong dugaan adanya struktur patahan F8, F9, dan F10.

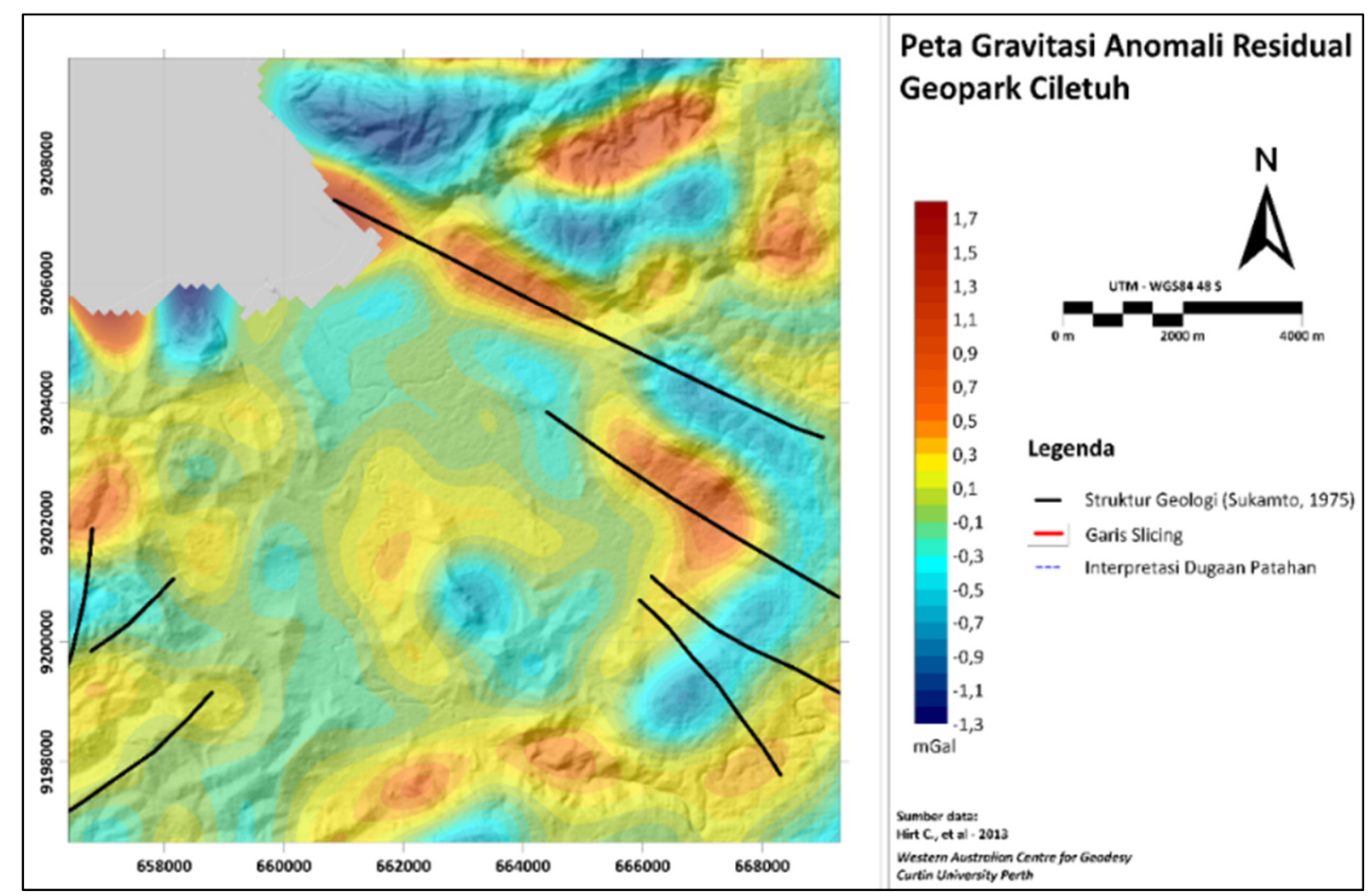

Gambar 5. Peta Gayaberat A nomali Bouguer Residual. 


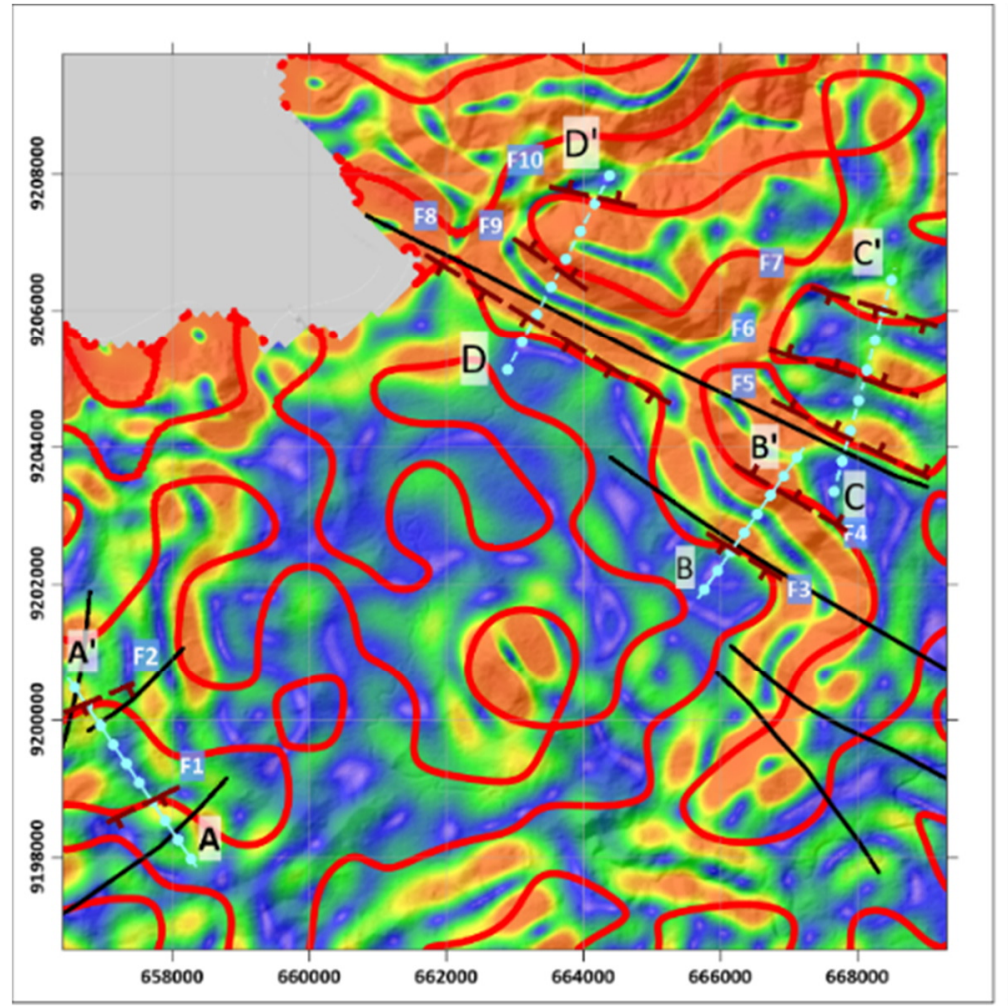

\section{Peta Gravitasi Anomali FHD Geopark Ciletuh}

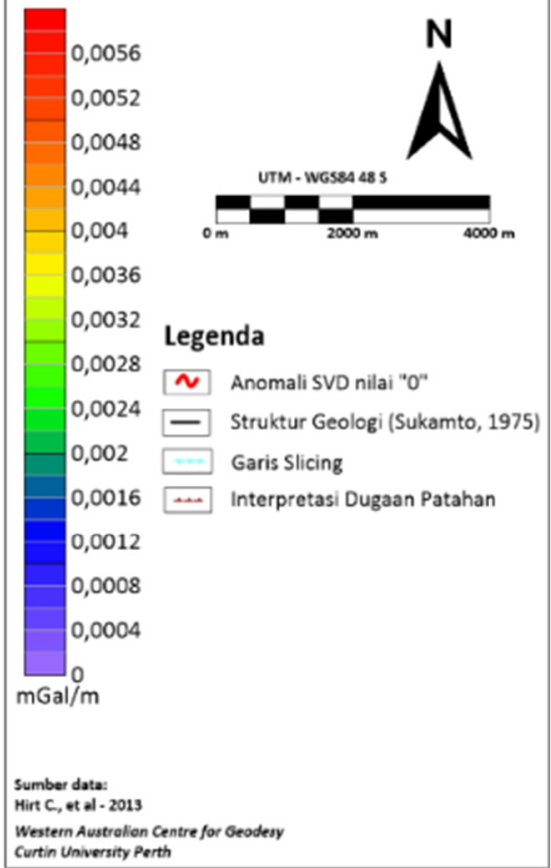

Gambar 6. Peta Gayaberat Anomali FHD.

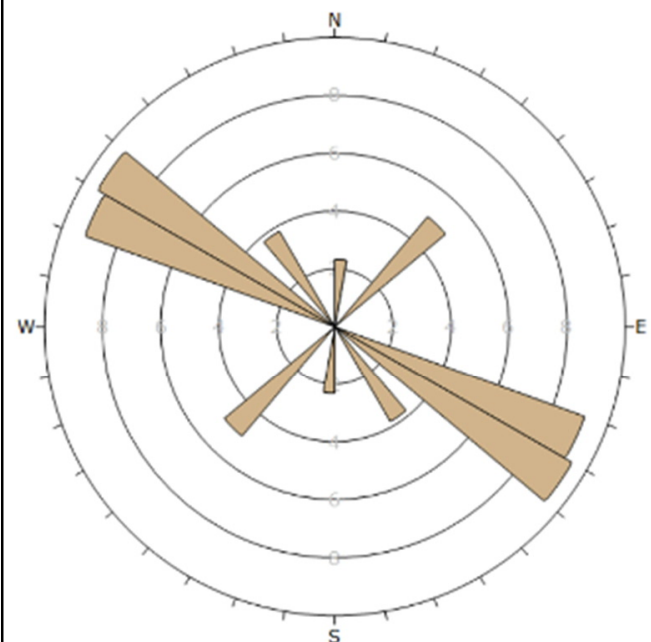

Geological Strike

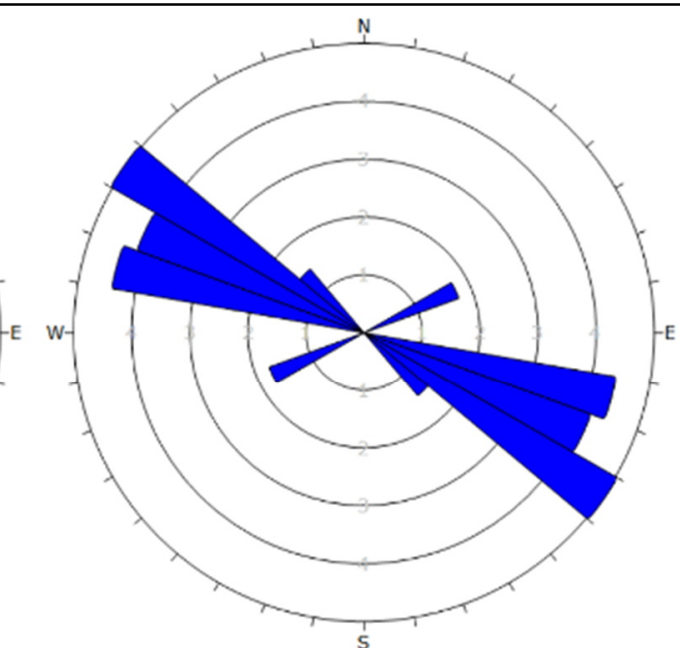

Geophysical Strike

Gambar 7. Diagram Rosset Arah Geological dan Geophysical Strike Stuktur Pada Geopark Ciletuh dengan masing-masing data berjumlah 10 data. 


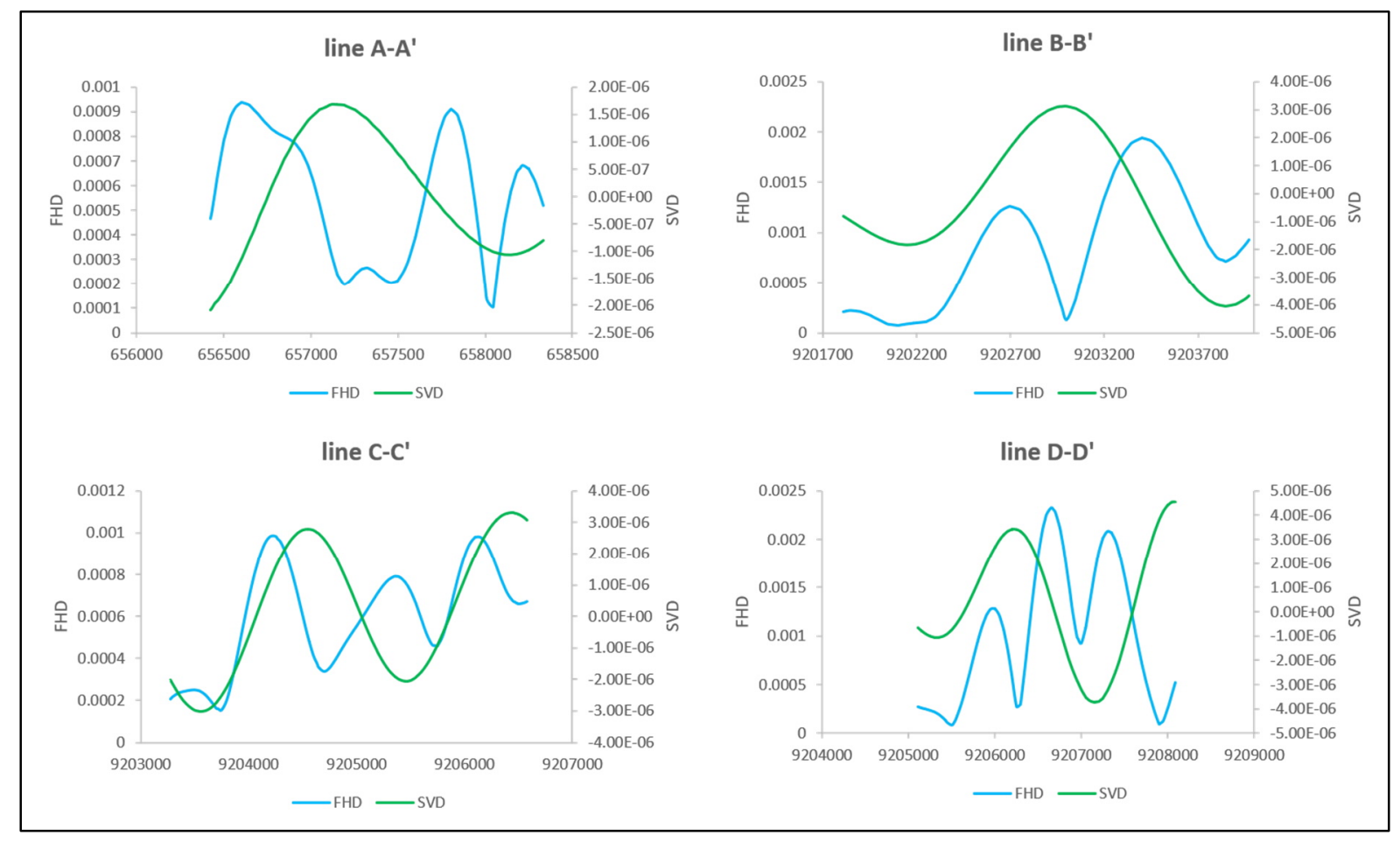

Gambar 8. Kurva FVD (biru) dan SVD (hijau) dari Setiap Line.

\subsection{Analisis ML-SVD}

Berdasarkan Gambar 9, dapat dilihat pada wilayah penelitian memiliki variasi arah dip yang bermacam-macam dan terlihat juga berbagai macam dugaan adanya struktur (patahan atau lipatan). A kan tetapi, penelitian ini hanya berfokus pada slicing line A-A' hingga D-D' yang di dalamnya terdapat adanya interpretasi dugaan patahan mulai dari F1 hingga F10. Dugaan patahan F1 dan F2 memiliki arah dip SE. Untuk dugaan patahan F3, F7, dan F8 memiliki arah dip SW. Sedangkan untuk dugaan patahan F4, F5, F6, F9, dan F10 memiliki arah dip NE.

Respon SVD nilai nol dijadikan acuan karena mengindikasikan batas dari fault location dari patahan yang terdeteksi pada M LSVD (Rosid \& Jaidi, 2020). Analisis ini berguna untuk membantu dalam mengurangi uncertainty dan meng-update geological cross section pada Peta Geologi Lembar Jampang Balekembang yang dibuat oleh Sukamto (1975) yang dirangkum pada Tabel 1.

\subsection{Analisis Terpadu}

M enurut Sukamto (1975), terdapat tujuh struktur geologi dalam wilayah penelitian yang berupa patahan dan berupa struktur antiklin dan sinklin. Area fokus penelitian ditandai dengan adanya interpretasi dugaan patahan F1 hingga F10 berdasarkan analisis data peta geologi Lembar Jampang Balekembang, data DEM, dan interpretasi patahan gayaberat dengan metode SVD, FHD, dan ML-SVD. Kemudian dibuat sebuah model tentatif geologi dari data-data tersebut. Dengan memanfaatkan analisis FHD untuk menentukan keberadaan patahan dan SVD mengonfirmasi jenis patahan, sedangkan MLSVD untuk melihat arah dip dan mengestimasi dip dari setiap patahan kemudian peta Geologi Lembar Jampang Balekembang oleh Sukamto (1975) digunakan untuk mengonfirmasi letak struktur, stratigrafi formasi, penamaan formasi dan menggunakan geological crosssection pada peta geologi untuk melihat batas kedalaman formasi batuan serta data DEM 
untuk melihat topografi permukaan dari tiap slicing line.

Berdasarkan Gambar 10, dapat dilihat visualisasi dari kolabaorasi data. Pada line A-A' terdapat adanya Formasi Ciletuh dengan sebuah struktur berupa antiklin dan sinklin (Sukamto, 1975). Akan tetapi, setelah dilakukan integrasi dengan data gayaberat, terlihat adanya sebuah patahan yang berada dekat dengan struktur antiklin dan sinklin yaitu berupa patahan normal pada F1 dan patahan naik pada F2. Patahan memiliki arah jurus NE-SW sesuai dengan pola Meratus (Hilmi \& Haryanto, 2008). Zona di antara F1 dan F2 diduga merupakan adanya keterbentukan horst, dikarenakan pada wilayah tersebut memiliki mekanisme pergerakan ke atas. Bila dikaitkan secara geologi, wilayah ini pernah terjadi pengangkatan dan dilanjutkan dengan erosi. Hal ini dapat terlihat pada bagian atas formasi tidak menunjukkan adanya ketinggian yang signifikan yang disebabkan oleh keterbentukan horst dikarenakan adanya proses erosi (Hilmi \& Haryanto, 2008).

Berdasarkan Gambar 10, dapat dilihat visualisasi integrasi data geologi dan gayaberat line B-B', C-C', dan D-D' terdapat adanya
Formasi Ciletuh yang berumur relatif lebih tua yaitu pada masa eosen dengan Anggota Cikarang yang berumur miosen awal yang juga terdapat struktur berupa patahan (Sukamto, 1975), Anggota Cikarang dan Formasi Jampang yang berdasarkan stratigrafi memiliki umur relatif yang sama yaitu pada masa miosen awal dengan terdapat adanya sebuah struktur berupa patahan, dan terdapat adanya Formasi Ciletuh yang berdasarkan stratigrafi berumur relatif lebih tua yaitu pada masa Eosen dengan Anggota Cikarang yang berumur miosen awal dengan terdapat adanya sebuah struktur berupa patahan (Sukamto, 1975).

Pada line B-B', diduga terdapat patahan F3 dan $\mathrm{F} 4$ dengan pergerakan normal dan naik secara berurutan. Pada line C-C', diinterpretasikan terdapat tiga dugaan patahan, yaitu F5, F6, dan F7, sedangkan pada line $D-D^{\prime}$ diduga juga memiliki tiga patahan, yaitu F8, F9, dan F10. Kedelapan patahan ini memiliki pola jurus yang bersesuaian dengan pola Sumatra (NW-SE). H al ini sesuai dengan data geologi pada periode Plio-Plistosen terjadi tektonik kompresi yang menghasilkan Pola Sumatra (H ilmi \& H aryanto, 2008). 


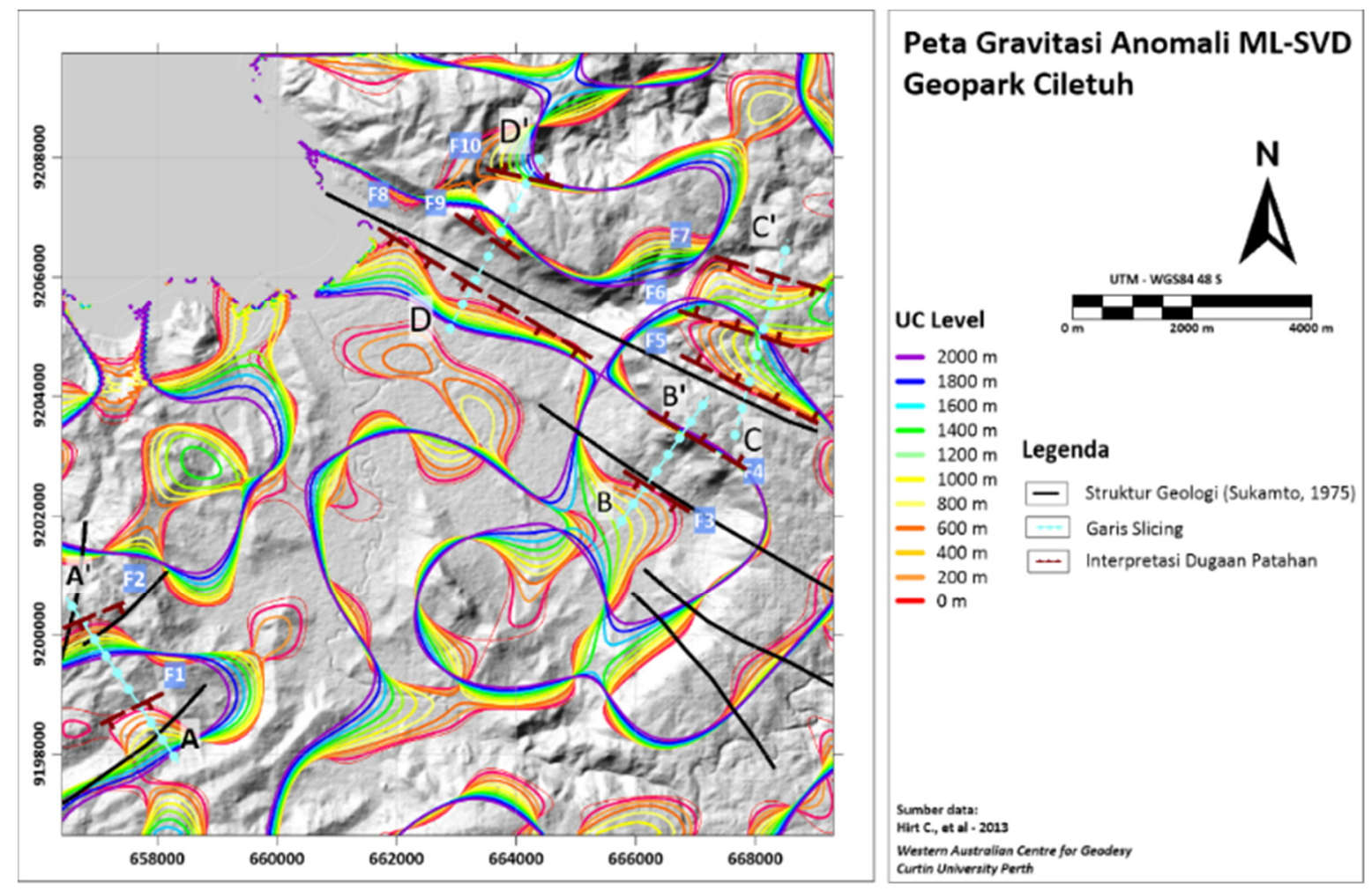

Gambar 9. Peta Gayaberat A nomali M L-SV D Geopark Ciletuh.

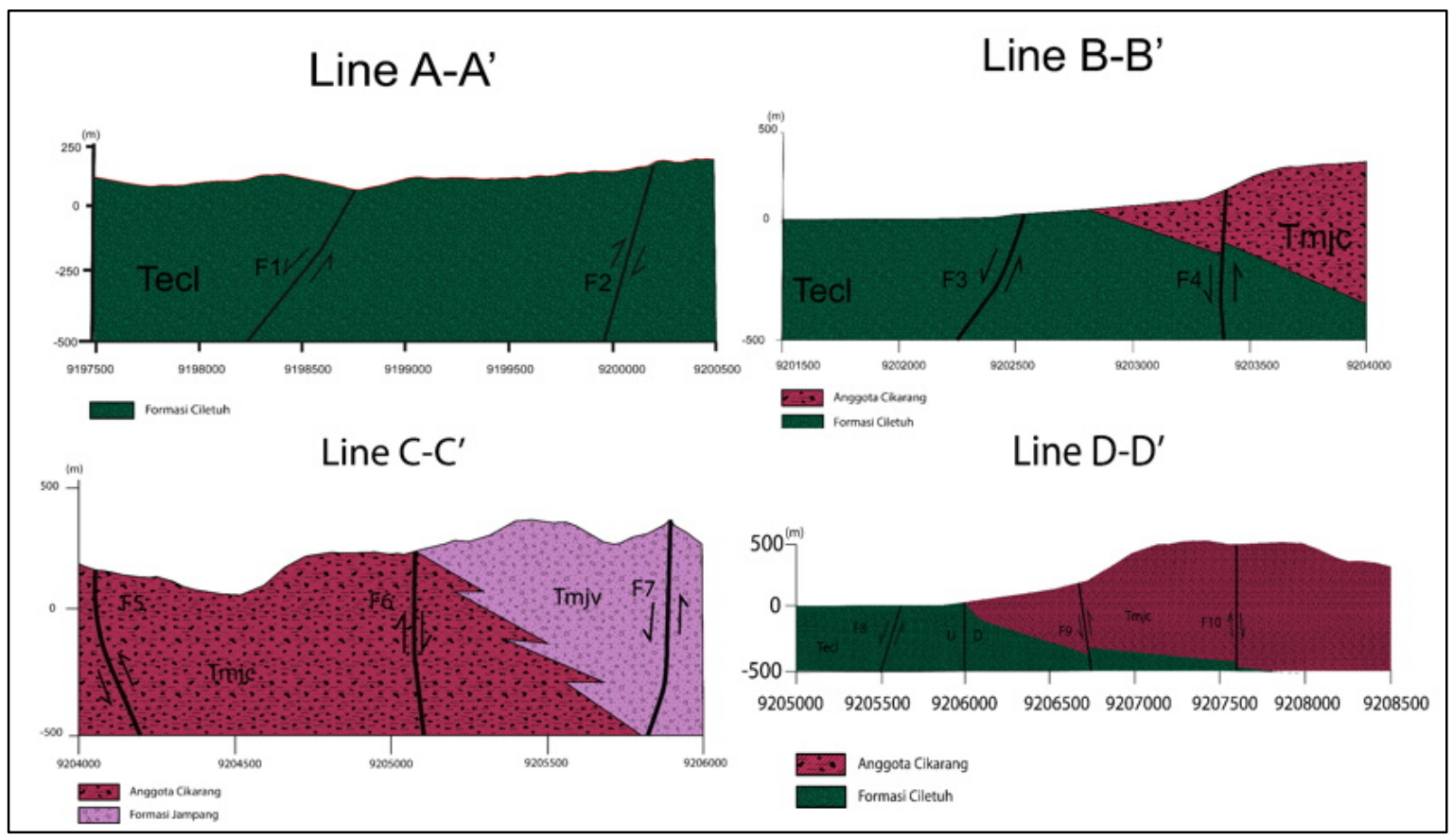

Gambar 10. Model konseptual line A-A', line B-B', line C-C', dan line D-D'. 
Tabel 1. Lokasi, karakterisasi patahan berdasarkan analisis M L-SVD dan SVD. Penentuan nilai dip dari masingmasing patahan dilakukan dengan menghitung nilai arctan dari gradien (M).

\begin{tabular}{|c|c|c|c|c|c|c|c|c|c|c|}
\hline \multirow{2}{*}{ UC } & \multicolumn{2}{|c|}{ Line AA' } & \multicolumn{2}{|c|}{ Line BB' } & \multicolumn{3}{|c|}{ Line C C' } & \multicolumn{3}{|c|}{ Line DD' } \\
\hline & F1 & F2 & F3 & F4 & F5 & F6 & F7 & F8 & F9 & F10 \\
\hline 0 & 9198800 & 9200200 & 9202525 & 9203390 & 9204090 & 9205065 & 9205875 & 9205650 & 9206690 & 9207590 \\
\hline-200 & 9198750 & 9200150 & 9202465 & 9203385 & 9204120 & 9205070 & 9205865 & 9205590 & 9206710 & 9207590 \\
\hline-400 & 9198660 & 9200090 & 9202395 & 9203380 & 9204165 & 9205090 & 9205835 & 9205540 & 9206733 & 9207590 \\
\hline-600 & 9198550 & 9200050 & 9202300 & 9203380 & 9204230 & 9205100 & 9205800 & 9205485 & 9206760 & 9207590 \\
\hline-800 & 9198450 & 9200000 & 9202170 & 9203380 & 9204320 & 9205110 & 9205745 & 9205433 & 9206790 & 9207600 \\
\hline-1000 & 9198300 & 9199900 & 9202000 & 9203385 & 9204430 & 9205130 & 9205650 & 9205380 & 9206822 & 9207615 \\
\hline-1200 & 9198225 & 9199850 & 9201800 & 9203390 & 9204610 & 9205175 & 9205480 & 9205345 & 9206845 & 9207645 \\
\hline-1400 & 9198150 & 9199800 & & 9203400 & & & & 9205305 & 9206880 & 9207685 \\
\hline-1600 & 9198100 & 9199750 & & 9203410 & & & & 9205265 & 9206910 & 9207740 \\
\hline-1800 & 9198050 & 9199700 & & 9203420 & & & & 9205235 & 9206940 & 9207820 \\
\hline-2000 & 9198000 & 9199650 & & 9203435 & & & & 9205210 & 9206945 & 9207910 \\
\hline $\begin{array}{c}\text { Dip } \\
\text { Direction }\end{array}$ & SE & SE & SW & $\mathrm{NE}$ & NE & NE & SW & SW & $N E$ & $N E$ \\
\hline$M$ & 2,2668 & 3,5205 & 1,6029 & 29,786 & 2,2194 & 10,903 & 2,8066 & 4,4405 & 7,2428 & 5,3697 \\
\hline Dip & 66,20 & 74,14 & 58,04 & 88,08 & 65,74 & 84,76 & 70,34 & 77,31 & 82,14 & 79,45 \\
\hline$\left|\left[\delta^{2} \mathbf{g} / \delta \mathbf{z}^{2}\right]\right|$ & $\begin{array}{c}\mid \text { Max } \mid> \\
\mid \text { in } \mid\end{array}$ & $\begin{array}{c}\mid \text { Max } \mid< \\
\mid \text { in } \mid\end{array}$ & $\begin{array}{c}\mid \text { Max } \mid> \\
\mid \text { in } \mid\end{array}$ & $\begin{array}{c}\mid \text { Max } \mid< \\
\mid \text { in } \mid\end{array}$ & $\begin{array}{c}\mid \text { Max } \mid< \\
\mid \text { in } \mid\end{array}$ & $\begin{array}{c}\mid \text { Max } \mid> \\
\mid \text { in } \mid\end{array}$ & $\begin{array}{c}\mid \text { Max } \mid> \\
\mid \text { in } \mid\end{array}$ & $\begin{array}{c}\mid \text { M ax } \mid> \\
\mid \text { in } \mid\end{array}$ & $\begin{array}{c}\mid \text { Max } \mid< \\
\mid \text { in } \mid\end{array}$ & $\begin{array}{c}|\mathrm{Max}|> \\
\mid \mathrm{M} \text { in } \mid\end{array}$ \\
\hline Fault Type & Normal & Reverse & Normal & Reverse & Reverse & Normal & Normal & Normal & Reverse & Normal \\
\hline
\end{tabular}

\section{KESIMPULAN}

Berdasarkan data gayaberat, setidaknya didapatkan sepuluh interpretasi dugaan patahan. Di mana F1, F3, F6, F7, F8, dan F10 mempunyai tipe patahan normal, sedangkan patahan F2, F4, F5, dan F9 dengan tipe patahan naik.

Kemudian arah strike yang didapatkan dari data gayaberat memiliki kesamaan dengan arah jurus yang ditampilkan pada peta geologi Jampang Balekembang.

Kemudian pada line $A-A^{\prime}$ ditemukan sebuah patahan baru dari data gayaberat GGM plus yang lokasinya berada dekat dengan struktur antiklin dan sinklin yang ditampilkan pada peta geologi.

Pada line B-B' ditemukan mekanisme pergerakan yang tidak sama diantara patahan yang berhimpitan yang di dapatkan dari data gayaberat GGM plus dengan yang ditampilkan pada peta geologi.

Pada line C-C' dan D-D' ditemukan mekanisme pergerakan yang memiliki kesesuaian antara patahan yang berdekatan yang didapatkan dari data gayaberat GGM plus dengan yang ditampilkan pada peta geologi.

\section{UCAPAN TERIMA KASIH}

Penulis mengucapkan terima kasih kepada Bapak A. Hafidz, M.T dan Bapak Gamma A bdul Jabbar, M .Sc. yang telah memberi kritik dan masukan terhadap hasil penelitian ini sehingga menjadi lebih baik.

\section{DAFTAR PUSTAKA}

Andriany, S. S., Fatimah, M. R., \& Hardiyono, A. (2016). Geowisata Geopark Ciletuh: Geotrek Mengelilingi Keindahan Mega Amfiteater Ciletuh (the Magical of Ciletuh A mphitheater). Bulletin of Scientific Contribution, 14(1), 75- 88. 
Blakely, R. J. (1995). Potential Theory in Gravity and Magnetic Applications. Cambridge University Press. https://doi.org/10.1017/CBO 9780511549816

Fitriani, D. S., Putri, S. N. A., \& Fauzan, I. (2020). Metode Gravitasi Untuk Identifikasi Sesar Weluki Dengan Analisis First Horizontal Derivative Dan Second Vertical Derivative. Prosiding Seminar Nasional Fisika, IX, 53-60.

Fitriastuti, A., Aristo, \& Putri, F. F. (2019). Identifikasi Struktur Bawah Permukaan M enggunakan M etode Gaya Berat A nalisis First Horizontal Derivative (FHD) dan Second Vertical derivative (SVD), Guna U paya M itigasi Bencana Gempabumi di Kabupaten Wonosobo, Provinsi Jawa Tengah. Prosiding Seminar Nasional Kebumian Ke-12, 604-614.

Hidayat, N., \& Basid, A. (2011). Analisis Anomali Gravitasi Sebagai Acuan Dalam Penentuan Struktur Geologi Bawah Permukaan Dan Potensi Geothermal (Studi Kasus Di Daerah Songgoriti Kota Batu). Jurnal Neutrino, 4(10), 35-47.

Hilmi, F., \& Haryanto, I. (2008). Pola Struktur Regional Jawa Barat. Bulletin of Scientific Contribution, 6(1), 57-66.

Jhanesta, W., \& Supriyanto. (2021). Application of Multi-Level Second Vertical Derivative (MLSVD) Method to Identify Subsurface Structure in Mount Endut Geothermal Prospect Area, Indonesia. The 2nd Digital Indonesia International Geothermal Convention 2021.

Kearey, P., Brooks, M., \& Hill, I. (2002). An Introduction to Geophysical Exploration 3rd Edition. Blackwell Publishing.
Reynolds, J. M. (1997). An Introduction to A pplied and Environmental Geophysics. John Wiley and Sons.

Rosana, M. F., M ardiana, U., Syafri, I., Sulaksana, N., \& Haryanto, I. (2006). Geologi Kawasan Ciletuh, Sukabumi : Karakteristik, Keunikan dan Implikasinya.

Rosid, M. S., \& Jaidi, F. (2020). Identification of Geological Structure in Bekasi City Using MSSVD Method Gravity Data. AIP Conference Proceedings, 2256(September).

Rosid, M. S., \& Siregar, H. (2017). Determining Fault Structure Using First Horizontal Derivative (FHD) and Horizontal Vertical Diagonal Maxima (HVDM) Method: A Comparative Study. AIP Conference Proceedings, 1862(July).

Sarmili, L., \& Setiady, D. (2015). Pembentukan Prisma Akresi Di Teluk Ciletuh Kaitannya Dengan Sesar Cimandiri, Jawa Barat. Jurnal Geologi Kelautan, 13(3), 173.

Sriyanto, S. P. D., \& Ifantyana, I. (2016). Identifikasi Patahan Mikro Penyebab Gempa Bumi Tarakan 21 Desember 2015. Prosiding Seminar Nasional Fisika, V, SN F2016-EPA-79-SN F2016-EPA-84.

Sukamto, R. (1975). Geologi Lembar Jampang dan Balekambang, Skala 1:100.000. Direktorat Geologi Bandung.

Wachidah, N., \& M inarto, E. (2018). Identifikasi Struktur Lapisan Bawah Permukaan Daerah Potensial Mineral dengan Menggunakan Metode Gravitasi di Lapangan "A", Pongkor, Jawa Barat. Jurnal Sains Dan Seni ITS, 7(1), 3237. 